\title{
Health indicators associated with poor sleep quality among university students*
}

\author{
INDICADORES DE SAÚDE ASSOCIADOS COM A MÁ QUALIDADE DO SONO DE \\ UNIVERSITÁRIOS
}

\section{INDICADORES DE SALUD ASOCIADOS CON LA MALA CALIDAD DEL SUEÑO DE LOS UNIVERSITARIOS}

\author{
Márcio Flávio Moura de Araújo1, Roberto Wagner Júnior Freire de Freitas², Adman Câmara Soares \\ Lima $^{3}$, Dayse Christina Rodrigues Pereira ${ }^{4}$, Maria Lúcia Zanetti ${ }^{5}$, Marta Maria Coelho Damasceno ${ }^{6}$
}

\begin{abstract}
Objective: to associate the sleep quality of Brazilian undergraduate students with health indicators. Method: A cross-sectional study was developed with a random sample of 662 undergraduate students from Fortaleza, Brazil. The demographic data, Pittsburgh Sleep Quality Index and health data indicators (smoking, alcoholism, sedentary lifestyle, nutritional condition and serum cholesterol) were collected through a self-administered questionnaire. Blood was collected at a clinical laboratory. In order to estimate the size of the associations, a Poisson Regression was used. Results: For students who are daily smokers, the occurrence of poor sleep was higher than in nonsmokers $(p<0.001)$. Prevalence rate values were nevertheless close to 1 . Conclusion: The likelihood of poor sleep is almost the same in smokers and in alcoholics.
\end{abstract}

\section{DESCRIPTORS}

Sleep

Students

Life style

Sleep disorders

\section{RESUMO}

Objetivo: Associar a qualidade do sono de universitários brasileiros com indicadores de saúde. Método: Estudo transversal desenvolvido com uma amostra aleatória de 662 estudantes universitários de FortalezaBrasil. Foram coletados dados sociodemográficos, indicadores de saúde (tabagismo, alcoolismo, sedentarismo, estado nutricional e níveis séricos de colesterol) e o Índice de Qualidade do Sono de Pittsburgh através de um questionário autoadministrado. As amostras sanguíneas foram analisadas em um laboratório clínico e para estimar a magnitude das associações foi adotada a Regressão de Poisson. Resultados: Nos universitários que fumam diariamente a ocorrência de má qualidade do sono foi superior em relação aos não fumantes $(p<0,001)$. Contudo, a razão de prevalência foi de aproximadamente 1. Conclusão: As chances de apresentar má qualidade do sono foram praticamente idênticas entre tabagistas e etilistas.

\section{DESCRITORES \\ Sono \\ Estudantes \\ Estilo de vida \\ Transtornos do sono}

\section{RESUMEN}

Objetivo: Asociar la calidad del sueño de los universitarios brasileños con los indicadores de salud. Método: Estudio transversal desarrollado con una muestra aleatoria de 662 estudiantes universitarios de Fortaleza, Brasil. Fueron recogidos datos sociodemográficos, indicadores de salud (tabaquismo, alcoholismo, sedentarismo, estado nutritivo y niveles séricos de colesterol) y el Índice de Calidad del Sueño de Pittsburgh mediante un cuestionario autoadministrado. Las muestras sanguíneas fueron analizadas en un laboratorio clínico y para evaluar la magnitud de las asociaciones se adoptó la Regresión de Poisson. Resultados: En los universitarios que fuman diariamente la ocurrencia de mala calidad del sueño fue superior en su relación con los no fumadores $(p<0,001)$. Sin embargo, la razón de prevalencia fue de aproximadamente 1. Conclusión: Las probabilidades de presentar mala calidad del sueño fueron prácticamente idénticas entre tabaquistas y etilistas.

\section{DESCRIPTORES \\ Sueño \\ Estudiantes \\ Estilo de vida \\ Trastornos del sueño}

\footnotetext{
* Extracted by the thesis "Qualidade do sono de universitários e sua interface com a síndrome metabólica e indicadores de saúde", Federal University of Ceará, 2012. ${ }^{1}$ Adjunct Professor of the University for the International Integration of the Afro-Brazilian Lusophony (UNILAB), Redenção, Brazil. ${ }^{2}$ Adjunct Professor of the Federal University of Piauí (UFPI), Floriano, Brazil. ${ }^{3}$ Professor at the Faculty of Education and Culture of Ceará (FAECE), Fortaleza, Brazil. ${ }^{4}$ Professor at the Faculty of Juazeiro do Norte, Juazeiro do Norte, Brazil. ${ }^{5}$ Associate Professor of the School of Nursing of Ribeirão Preto (EERP) of the University of São Paulo (USP), Ribeirão Preto, Brazil. ${ }^{6}$ Professor on the Postgraduate Programme in Nursing of the Federal University of Ceará (UFC), Fortaleza, Brazil.
}

$\begin{aligned} \text { Rev Esc Enferm USP } & \text { Received: } 04 / 15 / 2014 \\ \text { 2014; 48(6):1083-90 } & \text { Approved: } 08 / 12 / 2014\end{aligned}$




\section{INTRODUCTION}

For many years, sleep was attributed the simple passive character of restorer of organic functions. We now know, however, that the quantity and/or quality of sleep is involved in the manifestation of various alterations in cognitive, psychological, immunological and/or metabolic function. Conversely, many social, political and cultural aspects may interfere with the quantity and/or quality of sleep ${ }^{(1)}$. In this way, health and human sleep are intimately connected, like a symbiotic process, with both positively or negatively affected, in accordance with the picture presented.

In the case of cardiovascular health, for example, deficiency in the quality and/or quantity of sleep may be a vulnerability factor. Current epidemiological studies have demonstrated that short duration sleep ( $<7$ hours) is strongly associated with general mortality, principally with cardiovascular diseases (CVD) and type 2 diabetes mellitus (DM 2), in relation to subjects who reported sleeping for more than 8 hours per night ${ }^{(1-2)}$. On the other hand, a meta-analysis observed that subjects who sleep for a long time ( $>9$ hours) and for a short time ( $<7$ hours) have a life expectancy reduced principally by CVD and cancer, above all in women ${ }^{(2)}$.

According to the findings of the literature, the global epidemic of obesity has been accompanied by a falling trend in the duration of sleep. Today, poor sleep quality has become a frequent social complaint and with this, the duration and quality of sleep are regarded as new risk factors for the development of obesity. For this reason, it is no surprise that scientific data indicates overeating, glucose intolerance, increase in weight and loss of lean body mass in those individuals with short duration ${ }^{(3)}$ sleep.

Moreover, loss of quality and/or quantity of sleep may also interfere in cholesterolemia. In order to elucidate this fact, studies were analysed, according to which problems of obstruction of the airways during sleep increase lipid peroxidation. These investigations also highlighted that individuals with long duration sleep are more vulnerable to the development of dislipidemias and hypercholesterolemia. There is still no conclusive biologically plausible explanation for this, or even for any relationship between sleep and lipid profile. Conjectures exist, such as: individuals with the habit of spending longer in bed (longer duration sleep) are more sedentary and/or overweight than others, inevitably entailing high lipid levels ${ }^{(4-6)}$.

On the other hand, there are lifestyle habits which prejudice quality and/or quantity of sleep and which consequently increase human vulnerability to the aforementioned health problems.

Alcohol, for example, is probably the sleep-inducing substance most widely used by humanity. At the same time, the repercussions of alcoholism on sleep may lead to differing results. During the first three hours after the use of alcohol, there is a reduction in latency and of rapid eye movement (REM) sleep and an increase in the nonREM (NREM) phase. During the second half of rest, interruption of sleep occurs due to gastric irritation, headache, nightmares, tachycardia and sweating. In addition to this, between 36 and $72 \%$ of alcoholics suffer from insomnia after months of abstinence. Another important detail is that normal sleep predominates in the parasympathetic nervous system, while the opposite occurs in alcoholics, leading to the emergence of cardiovascular problems ${ }^{(7-9)}$.

Smoking also demonstrates a negative relationship to sleep. Nicotine, the active component of cigarette smoke, stimulates the release of neurotransmitters which regulate sleep, including dopamine and serotonin, resulting in sleep disturbances. It also affects lung function and causes inflammation of the airways, generating a predisposition to snoring and apnoea. Smoking is still associated with disturbances in the structure of sleep, such as an increase in latency, excessive drowsiness during the day and a reduction in sleep ${ }^{(8-10)}$ efficiency.

Whether or not an individual is active may also interfere in sleep. For example, publications consulted verified that there was an increase in slow-wave sleep and a reduction in REM sleep after physical activity. Added to this, the American Sleep Association recommends regular physical exercise as a non-pharmacological intervention for promoting adequate sleep ${ }^{(11-13)}$.

As the aforementioned articles suggest, sleep problems, principally with regard to duration, are predictors of chronic health problems. In Brazil, non-transmissible chronic illnesses (NTCl) account for $72.4 \%$ of deaths. These illnesses have risk factors, including: smoking, alcoholism, physical inactivity, inadequate nutrition and obesity. All of these issues may be designated as population health indicators, since they represent measures consisting of relevant information on given attributes and dimensions of health status, as well as of the performance of the health care system. In this way, its monitoring and the establishment of causal relationships with other health, clinical and socio-demographic indicators is important ${ }^{(14)}$.

In an analysis of causality between sleep and health indicators, more important than duration is the quality of sleep. This concept takes into account the interaction of factors such as subjective personal evaluation, latency, duration, efficiency and the presence of sleep disturbances. The use of psychotropic medicines and excessive daytime drowsiness are also scored ${ }^{(15-16)}$.

The years that young people spend at university are frequently characterised by insufficient sleep, an increase in consumption of alcoholic and energy beverages and/or of caffeine. Furthermore, eating and sleep patterns are irregular, with possible negative repercussions on the general health and well-being of university students ${ }^{(7)}$. 
As far as we are aware, there are no publications developed with Brazilians with the objective of establishing associations between sleep quality and health indicators among university students. In this way, this proposal becomes relevant, since it aids in determining the size of the associability of daily issues such as lifestyle habits and nutritional condition with quality of sleep among young Brazilian adults.

In this way, the objective of this article was to verify associations between sleep quality among university students in the city of Fortaleza, Brazil with the following health indicators: smoking, alcoholism, sedentary lifestyle and nutritional condition. Furthermore, the association between sleep quality and serum levels of HDL-Cholesterol (HDL-C) and LDL-Cholesterol (LDL-C) was also investigated.

\section{METHOD}

\section{Design and location of the study}

Approximately 1,000 students at a public and federal university in Fortaleza, Brazil were recruited for the development of this cross-cutting study between 2011 and 2012. All areas of knowledge were represented through four centres (Science, Agricultural Sciences, Humanities and Technology) and five faculties (Law, Education, Economics, Management, Economic and Actuarial Sciences, Pharmacy, Dentistry and Nursing).

\section{Participants}

A simple random sample was calculated on the basis of number of students enrolled at the location of the study. On the basis of a formula for infinite populations, a percentage of $50 \%(P=50 \%$ and $Q=50 \%)$ was adopted, since this value provides a maximum sample size, when the level of significance $(\alpha=0.05)$ and the relative sample size of $8 \%$ (absolute error $=4 \%$ ) are fixed.

The calculation resulted in 701 university students stratified in accordance with the areas of knowledge: Humanities $(20.4 \%)$, Exact Sciences (16.5\%), Agricultural Sciences (14.0\%), Health (15.1\%), Science (18.1\%) and Technology (15.9\%). The inclusion criteria established were: age $\geq 18$, morning attendance, agreement to take part in all phases of data collection, having a contact fixed or mobile line and email, with pregnant and/or breastfeeding women excluded. Among all of the courses, two were selected from each area of knowledge. The researchers recruited students through invitations in lecture rooms, the display of posters around the university and individual dissemination. All participants signed the free and informed consent form. The study was approved by the Ethics Committee for Human Research of the Federal University of Ceará under protocol No. 208/10.

\section{Measurements}

Data collection occurred in two stages: completion of the instruments regarding sociodemographic data and health indicators and another day for collecting blood samples and anthropometric data. For each course, rooms were prepared to store research materials and to guarantee the privacy of university students during data collection. The nurses responsible for the data collection underwent 16 hours training in order to familiarise themselves with the instruments and thereby guarantee the reliability of the information.

\section{Sociodemographic variables}

The sociodemographic variables were collected through a questionnaire for self-completion, containing the following information: sex, age, self-defined colour; monthly family income; economic class (A1, A2, B1, B2, C, $\mathrm{D}$ or $\mathrm{E}$ ); course; period or semester of the course (freshers: from the first to half way through the course); veterans, starting from the second half of the course); job situation; marital status; and with whom is the student cohabiting.

\section{Variables related to lifestyle habits}

Students were classified as sedentary if they stated that they did not undertake physical activity on a regular basis, with a minimum frequency of three times a week and a minimum duration of 30 consecutive minutes per exercise.

Smoking was classified into four categories: daily smokers (those who smoked at least one cigarette a day for at least one month before the completion of the questionnaire); occasional smokers (those who do not smoke on a daily basis); ex-smokers (those who after having been smokers had stopped smoking at least a month ago); and non-smokers (who had never smoked or who had been smoking for less than a month) ${ }^{(17)}$.

In order to classify the pattern of alcohol consumption, a version validated in Brazil of the AUDIT [A/cohol Use Disorders Identification Test] was adopted. This is entirely reliable (Cronbach's Alpha) of 0.80 , indicating a high degree of internal consistency. The cited instrument divides alcohol consumption into four levels, varying from low risk of alcoholism to probable alcohol dependency ${ }^{(18)}$.

\section{Nutritional condition}

The nutritional condition of students was evaluated through the Body Mass Index (BMI). This variable was calculated and analysed, taking into consideration the recommendation of the World Health Organisation, i.e. considered as low if the $\mathrm{BMI}<18.5 \mathrm{Kg} / \mathrm{m}^{2}$; eutrophic, if $\geq 18.5$ and <25.0; overweight for values located between 25.0 and $29.9 \mathrm{Kg} / \mathrm{m}^{2}$; and obese for $\mathrm{BMI} \geq 30 \mathrm{Kg} / \mathrm{m}^{2(19)}$.

\section{Sleep quality}

Sleep quality was analysed on the basis of a validated version, translated and adapted to the Brazilian standards of the Pittsburgh Sleep Quality Index (PSQI). In the Brazilian Portuguese version, the scoring of 7
Health indicators associated with poor sleep quality among university students Araújo MFM, Freitas RWJF, Lima ACS, Pereira DCRP, Zanetti ML, Damasceno MMC 
PSQI items has a total reliability (Cronbach's alpha) of 0.83 , indicating a high degree of internal consistency. The sum of scores for these seven components produces a global score varying from 0 to 21 , on the basis of which, the highest score indicates the worst sleep quality. University students with scores exceeding five points were classified as poor sleepers ${ }^{(15)}$.

\section{Biochemical variables}

Phlebotomists trained by a private clinical analysis laboratory carried out the blood collection. The BD Vacutainer ${ }^{\circledR}$ vacuum collection system by venous puncture was used. The participants in the study submitted to a 12-hour fast for the biochemical determination of HDL-C. $5 \mathrm{ml}$ of blood was collected and stored in a tube without an anticoagulant. The samples were transported in a thermal box with ice to the laboratory for clinical analyses.

The collected samples were processed and centrifuged at $2200 \mathrm{rpm}$ for 20 minutes in a serological digital LS3 Plus CELM ${ }^{\circledR}$ centrifuge. Following this, doses of $1 \mathrm{ml}$ of serum and plasma were separated in order to realise the biochemical dosages. Diagnóstica $S / A^{\circledR}$ Commercial Labtest kits were used in the evaluation of biochemical parameters with standard techniques based on enzymatic and colorimetric methods, by spectrophotometry, pursuant to the recommendations of the manufacturer. The concentrations were determined using the Labmax $240^{\circledR}$ automatic biochemical analyser. The determination of the LDL-C was calculated using the Friedewald formula.

\section{Statistical analysis}

The data were entered on three occasions into an Excel spreadsheet and subsequently exported to the STATA 8.0 statistical software application. The triple entry was carried out with the aim of detecting erroneous, incomplete or missing information in the study database. The analysis of the data was preceded by an exploratory description of the health and sociodemographic indicators regarding sleep quality. This occurred through the generation of uni- and bivariate distributions and of asymmetric central trend measures in the quantitative variables.

The variables sex and monthly income showed an asymmetric distribution to the right (Kolmogorov Smirnov with $\mathrm{p}<0.001)$.

In order to verify the differences between the proportions of the health indicators and the PSQI Indicator, we use Pearson chi-squared or Fisher's Exact Test (where necessary). In order to analyse the relationship between the quantitative variables and sleep quality and the points of the PSQI, we adopt the Mann-Whitney Test, due to the asymmetric distribution of the variables, a fact which entailed the use of non-parametric methods.

In order to estimate the size of the associations we use prevalence of poor sleep quality as a frequency measure. As a measure of association we use the Prevalence Ratio (RP) and its respective 95\% confidence intervals, estimated as a function of the relative risk (RR) of the robust Poisson regression. In all analyses, we adopted a statistical significance level of $5 \%$. The use of the robust Poisson regression in this study was appropriate due to the high prevalence of poor sleep quality encountered in the study population $(96.4 \%)^{(20)}$. It should be emphasised that the size of the associations was adjusted for age and sex variables.

\section{RESULTS}

The study population consisted of 662 university students from six areas of knowledge, distributed over 24 undergraduate courses. There was a higher participation of females (62.6\%), with an average sample age of 21.5 years (SD \pm 4.5 years).

With regard to colour, university students declared themselves to be mixed race $(50.6 \%)$, white $(36.1 \%)$, black (7.8\%) and yellow (5.6\%). There was a predominance of students in the third $(20,8 \%)$ and first semester $(19.5 \%)$. Essentially, the university students were single (93\%), lived with their parents (71.2\%) and studied full time (i.e. were not reconciling employment and study).

The students principally derived from the $C(39.6 \%)$ and $\mathrm{B}(39.7 \%)$ economic classes, regarded as having average purchasing power in Brazil. The students lived with a monthly family income of $\mathrm{R} \$ 1,064$ (SD $\pm 122,7$ ). It is important to highlight that $15 \%$ of participants did not state the value of their monthly income.

Excess weight was detected in $26.4 \%$ of students, with $21.3 \%$ overweight and $5.1 \%$ obese, respectively. In the investigated sample, we verified that $70.2 \%$ were sedentary, $8.5 \%$ smokers and $6.6 \%$ alcoholics.

There were no statistically significant differences between smoking and levels of LDL-C by sex. The sedentary lifestyle was greater among women $(77.3 \%)$ relative to men $(20.7 \%)(p<0.001)$. Female university students had a lower percentage of low risk of alcoholism (3.9\%) than the male university students $(11.1 \%)(p<0.001)$.

A small portion of the sample showed high serum levels of LDL-C (5.8\%) and low levels of HDL-C (12\%). On average, levels of LDL-C were $74.6 \mathrm{mg} / \mathrm{dl}(\mathrm{SD} \pm 33.5 \mathrm{mg} / \mathrm{dl})$ and $53.7 \mathrm{mg} / \mathrm{dl}$ for HDL-C (SD $\pm 33.5 \mathrm{mg} / \mathrm{dl})$. Reduced serum levels of HDL-C predominated among women (89.2\%) $(p<0.001)$.

A substantial portion of the sample reported poor sleep quality (96.4\%). We did not identify statistically significant proportional differences between university students who were good and poor sleepers and the health indicators (smoking, sedentary lifestyle, alcoholism, nutritional condition and serum cholesterol levels) (Table 1). 
Table 1 - Characteristics of the health indicators of university students with regard to sleep quality. Fortaleza, Brazil, 2012.

\begin{tabular}{|c|c|c|c|c|c|}
\hline \multirow{3}{*}{$\begin{array}{l}\text { Health indicators } \\
\text { BMI }\end{array}$} & \multicolumn{4}{|c|}{ PSQI } & \multirow{2}{*}{ p Value } \\
\hline & \multicolumn{2}{|c|}{ Good sleepers 31(3.6\%) n (\%) } & \multicolumn{2}{|c|}{ Poor sleepers 631(96.4\%) n (\%) } & \\
\hline & & & & & \\
\hline Underweight & 5 & 16.2 & 36 & 5.7 & \\
\hline Eutrophic & 21 & 67.7 & 431 & 68.3 & \\
\hline Overweight & 4 & 12.9 & 131 & 20.8 & \\
\hline Obese & 1 & 3.2 & 33 & 5.2 & \\
\hline Average BMI & \multicolumn{2}{|c|}{21.2} & \multicolumn{2}{|c|}{22.6} & $0.039 *$ \\
\hline Average $\pm \mathrm{SD}$ & \multicolumn{2}{|c|}{$22.1 \pm 3.86$} & \multicolumn{2}{|c|}{$23.2 \pm 3.77$} & \\
\hline \multicolumn{6}{|l|}{ Practice of physical activity } \\
\hline Active & 12 & 38.7 & 188 & 29.6 & $0.187 \dagger$ \\
\hline Sedentary & 19 & 61.3 & 443 & 70.4 & \\
\hline \multicolumn{6}{|l|}{ Smoking } \\
\hline Daily smoker & - & - & 12 & 1.6 & $0.188 \div$ \\
\hline Ex-smoker/Occasional smoker & 5 & 16.1 & 47 & 7.3 & \\
\hline Never smoked & 26 & 83.9 & 573 & 91.1 & \\
\hline \multicolumn{6}{|l|}{ Alcoholism } \\
\hline Low risk & 31 & 100.0 & 586 & 92.9 & $0.106 \leftrightarrows$ \\
\hline Medium risk & - & - & 45 & 7.1 & \\
\hline \multicolumn{6}{|l|}{ LDL - C } \\
\hline Normal & 27 & 87.1 & 594 & 94.1 & $0.117 \dagger$ \\
\hline High & 4 & 12.9 & 37 & 5.9 & \\
\hline \multicolumn{6}{|l|}{ HDL-C } \\
\hline Normal & 28 & 91 & 557 & 88.2 & $0.787 \dagger$ \\
\hline Low & 3 & 9 & 74 & 11.8 & \\
\hline
\end{tabular}

Notes: *Mann-Whitney Test; † Fisher’s exact chi squared test; $\ddagger$ Pearson’s chi squared test.

There was no statistically significant correlation between the PSQI score and HDL-C levels in both analysed groups: $\operatorname{good}(p=0.728)$ and poor sleepers $(p=0.509)$.
In the correlation between the PSQI score and LDL-C levels, the same result occurred: good $(p=0.478)$ and poor sleepers $(p=0.728)$.

Table 2 - Association between poor sleep quality and health indicators plus PSQI among university students. Fortaleza - Brazil, 2012.

\begin{tabular}{|c|c|c|c|c|}
\hline Health indicators & Prevalence in group $\mathbf{n}(\%)$ & Prevalence Ratio & 95\%* Confidence interval & p Value \\
\hline $\begin{array}{l}\text { Prevalence of poor sleep quality } \\
\text { in the study population }\end{array}$ & $631(96.4)$ & & & \\
\hline \multicolumn{5}{|l|}{ Practice of physical activity } \\
\hline Active & $193(93.7)$ & 1.00 & -- & -- \\
\hline Sedentary & $472(95.9)$ & 1.03 & $1.00-1.07$ & 0.147 \\
\hline \multicolumn{5}{|l|}{ Smoking } \\
\hline Daily smoker & $10(95.6)$ & 1.00 & -- & -- \\
\hline Ex-smoker/Occasional smoker & $46(100)$ & 1.04 & $1.02-1.06$ & $<0.001$ \\
\hline Never smoked & $570(90.7)$ & 0.94 & $0.86-1.03$ & 0.201 \\
\hline \multicolumn{5}{|l|}{ Alcoholism } \\
\hline Low risk & $622(95)$ & 1.00 & -- & -- \\
\hline Medium risk & $46(100)$ & 1.05 & $1.03-1.07$ & $<0.001$ \\
\hline \multicolumn{5}{|l|}{ BMI } \\
\hline Underweight & $451(95.4)$ & 1.00 & -- & -- \\
\hline Eutrophic & $35(94.6)$ & 0.98 & $0.91-1.07$ & 0.710 \\
\hline Overweight & $147(96.7)$ & 1.00 & $0.97-1.04$ & 0.621 \\
\hline Obese & $34(89.5)$ & 0.94 & $0.83-1.05$ & 0.257 \\
\hline \multicolumn{5}{|l|}{ LDL-C } \\
\hline Normal & $618(95.2)$ & 1.00 & -- & -- \\
\hline High & $38(95)$ & 0.99 & $0.92-1.07$ & 0.860 \\
\hline \multicolumn{5}{|l|}{ HDL-C } \\
\hline Normal & $605(95.8)$ & 1.00 & -- & -- \\
\hline Low & $26(98.0)$ & 1.03 & $0.99-1.08$ & 0.124 \\
\hline
\end{tabular}

Notes: *Estimated on the basis of the Robust Poisson Regression, adjusted for age and sex.

Health indicators associated with poor sleep quality among university students Araújo MFM, Freitas RWJF, Lima ACS, Pereira DCRP, Zanetti ML, Damasceno MMC 
A positive and statistically significant association was identified between poor quality of sleep and daily smoking $(p<0.001)$ and moderate risk of alcoholism $(p<0.001)$. At the same time, the prevalence ratio values were close to 1 . Hence, the chances of poor sleep quality are virtually equal in these groups (Table 2).

\section{DISCUSSION}

A high percentage of university students were characterised as poor sleepers. It should be highlighted that only university students who took part in the interview and collection of laboratory tests and BMI were included in the study. These events took place on different days. In this way, even with the random character of the sample selection, it is possible that young people with suspected or already established sleep problems had a greater interest in taking part in all stages of the research relative to healthy young people, with this causing a high prevalence of poor sleep quality.

A substantial portion of the sample were described as poor sleepers, albeit who did not smoke or drink. Perhaps for this reason, within this survey, the chances of presenting poor sleep quality were practically identical between university students who smoked daily and those with a moderate risk of alcoholism.

With regard to use of alcohol, studies with the same population detected results which were both similar to and the opposite of this article. These authors also highlighted that alcohol has a synergistic relationship with sleep deprivation, which increases chances of road accidents and reduces the academic performance of university students ${ }^{(7,8)}$. Studies carried out on adults in turn highlighted a statistically significant association between alcohol use and the development of sleep apnoea, poor sleep quality and sleep problems ${ }^{(9,21-22)}$.

In the case of smoking, the studies consulted presented values similar to and higher than this study. In this latter case, the publications confirm and of two and up to three times in the emergence of sleep problems, such as apnoea, storing and insomnia among smokers ${ }^{(8,10,23)}$. Another important detail is that these findings were also repeated with samples of adults, pregnant women, adolescents and children ${ }^{(24-25)}$.

Globally, one of the principal problems is the fact that university students are only familiar with the detrimental effect of caffeine on sleep health, while the link with the use of alcohol and tobacco goes unnoticed. This is a matter for concern, since smokers with poor sleep quality usually also consume more alcohol and caffeine in association with tobacco, impairing sleep health even more ${ }^{(8)}$. Hence, the use of tobacco and alcohol by university students cannot go unnoticed for anyone drawing up public policies to promote health, since in the future, this may reduce the prevalence of middle-aged adults with sleep problems and NTCl.

Use of tobacco is currently exhaustively condemned but perhaps for this reason, the use of smaller cigarettes or even cigarillos is growing among university students. The persistence of this habit among university students appears to be related to the search for different sensations and stress relief. In the case of alcohol, in Brazil, getting drunk is more common among university students than among the general population and high school students ${ }^{(26)}$. In general, it is common for university students to go to bars, nightclubs and other venues for entertainment and leisure. Such experiences lead to the excessive consumption of alcohol, which may be considered as normal cultural behaviour. Furthermore, the use of alcohol may be related to issues of low self-esteem, professional and/or personal problems and peer pressure ${ }^{(26-27)}$.

As such, it is important to highlight the desire among many young people to differentiate or distinguish themselves from others, whether through physical attributes, dress or habits which place them at an advantage or make them accepted among existing groups, even if the extent of these factors is detrimental to their health. This perhaps explains in part the persistence of smoking and drinking among young university students, who are familiar with the evils of these habits.

In this study, there were no statistically significant associations between serum cholesterol levels and sleep quality. The located publications in turn confirmed statistically significant associations between LDL-C or HDL-C and poor quality sleep ${ }^{(4-6)}$. At the same time, the located studies were carried out principally among adults, the elderly or middle-aged people. This population could already present chronic health problems related to hypercholesterolemia and/or dislipidemia.

Like cholesterol levels, a sedentary lifestyle also presented no significant association with the sleep quality of university students. In similar fashion, three studies carried out in Brazil with sedentary young adults did not identify any association between regular physical exercise and improvements in sleep patterns ${ }^{(12-13,28)}$.

Like these three cited Brazilian studies, the divergence between the data of this investigation and other investigations may arise from methodological divergences in the definition of physical activity or also from the low intensity of exercise carried out by young people. In any case, in addition to the benefits of sleep, it is valid to recommend the regular practice of physical activity for university students, since this habit is regarded as an important positive predictor for human health in general.

Since this study relates to young people who are poor sleepers, albeit without vices, it is possible to hypothesise other issues as a factor related to the high 
degree of prevalence of poor sleep quality in the sample of this study.

The excessive use of technological mechanisms, such as televisions, computers or mobile phones to access social networks may be highlighted. For example, addiction to smartphones and tablets may cause insomnia, weight gain and even illnesses. This explanation by the authors is based on the fact that the lighting of telephones and portable computers may reduce the organic production of the sleep regulating hormone: melatonin. This may cause insomnia, especially in adolescents, young adults and the elderly, since these are individuals who are commonly active at night ${ }^{(29)}$. This suppression of melatonin may also be responsible for cases of obesity, DM 2 and even breast cancer ${ }^{(30)}$.

No robust evidence was found for an association between poor sleep quality and the health indicators described in the methodology. It is important to highlight that there was a control of the age and sex variables in these associations. Despite this, it is important to highlight the youth of the sample. It is likely that among adults, the elderly or middle-aged people who have been smokers and drinkers for longer that these associations may be statistically more robust. The same reasoning applies to physical inactivity, excess weight and hypercholesterolaemia, which are more detrimental to mature individuals.

In this way, it is advisable that studies with a longitudinal design are developed with the aim of remeasuring the size of the association between sleep quality and the health indicators smoking, drinking, sedentary lifestyle, excess weight and hypercholesterolaemia.

\section{REFERENCES}

1. Li D, Liu D, Wang X, He D. Self-reported habitual snoring and risk of cardiovascular disease and all-cause mortality. Atherosclerosis. 2014;235(1):189-95.

2. Galilicchio L, Kalesan B. Sleep duration and mortality: a systematic review and meta-analysis. J Sleep Res. 2009;18(2):148-58.

3. Knutson KL. Sleep duration and cardiometabolic risk: a review of the epidemiologic evidence. Best Pract Res Clin Endocrinol Metab. 2010;24(5):731-43.

4. Petrov ME, Kim Y, Lauderdale D, Lewis CE, Reis JP, Carnethon $M R$, et al. Longitudinal associations between objective sleep and lipids: the CARDIA study. Sleep. 2013;36(11):1587-95.

5. Toyama Y, Chin K, Chihara Y, Takahashi K, Sumi K, Nakamura T, et al. Association between sleep apnea, sleep duration, and serum lipid profile in an urban, male, working population in Japan. Chest. 2013;143(3):720-8.

\section{CONCLUSION}

On the basis of the results of this study, we may conclude that university students who smoke daily and have a medium risk of alcoholism show practically identical chances of presenting poor sleep quality as others.

It is important for healthcare professionals to monitor the evolution of these health indicators, principally in university students who are poor sleepers, in order to prevent the emergence of $\mathrm{NTCl}$. Nurses who interact directly with university students must carry out educational activities, in an academic or digital environment, which promote the sleep hygiene habits in the daily routine of these young people.

In the analysis of the data of this article, it is important to consider a number of limitations on this research. Since it is a cross-cutting study, it is not possible to establish causal relationships even in those items for which a statistically significant association was verified. The study adopted a psychometric scale in the evaluation of sleep quality of investigated individuals, which, despite being equivalent, is less accurate than other analytical methods, such as polysomnography and actigraphy. Furthermore, the PSQI data were self-referential, i.e. errors in their completion or lack of precise memories may have occurred. There was no control of the influence of eating habits on the measurement of LDL-C.

The study did not associate sleep quality with markers for vascular oxidation and other hormones involved in energy metabolism. We thus recommend the replication of this study with university students of other nationalities, with the correction of these aforementioned limitations in order to generate more robust evidence.

6. Lee J, Choi YS, Jeong YJ, Lee J, Kim JH, Kim SH, et al. Poorquality sleep is associated with metabolic syndrome in Korean adults. Tohoku J Exp Med. 2013; 231(4):281-91.

7. Kenney SR, Paves AP, Grimaldi EM, La Brie JW. Sleep quality and alcohol risk in college students: examining the moderating effects of drinking motives. J Am Coll Health. 2014;62(5):301-8.

8. Tamaki T, Kaneita Y, Ohida T, Yokoyama E, Osaki Y, Kanda H, et al. Prevalence of and factors associated with smoking among Japanese medical students. J Epidemiol. 2010;20(4):339-45.

9. Scanlan MF, Roebuck T, Little PJ, Redman JR, Naughton MT. Effect of moderate alcohol upon obstructive sleep apnoea. Eur Respir J. 2000;16(5):909-13.

10. Sabanayagam $C$, Shankar A. The association between active smoking, smokeless tobacco, second-hand smoke exposure and insufficient sleep. Sleep Med. 2011;12(1):7-11. 
11. Aurora RN, Zak RS, Auerbach SH, Casey KR, Chowdhuri S, Karippot $A$, et al. Best practice guide for the treatment of nightmare disorder in adults. J Clin Sleep Med. 2010;6(4):389-401.

12. Faria AP, Cavagnolli DA, Rossi MV, Ferreira SE, Bittencourt LRA, Tufik S, et al. Effects of resistance exercise on the sleep patterns of sedentary individuals. Sleep Sci. 2009;2(3):141-6.

13. Rossi MV, Cavagnolli DA, Faria AP, Ferreira SE, Koyama RG, Bailone Neto A, et al. Acute effect of different types of physical exercise on sleep patterns. Sleep Sci. 2010; 3(2):63-8.

14. Rede Interagencial de Informação para a Saúde (RIPSA). Indicadores e Dados Básicos para a Saúde no Brasil: conceitos e aplicações [Internet]. Brasília: OPAS; 2008 [citado 2013 out. 11]. Disponível em: http://disciplinas.stoa.usp.br/pluginfile.php/18248/mod_resource/content/1/RIPSA.pdf

15. Bertolazi AN, Fagondes SC, Hoof L, Dartora EG, Miozzo IC, Barba ME, et al. Validation of the Brazilian Portuguese version of the Pittsburgh Sleep Quality Index. Sleep Med. 2011;12(1):70-5.

16. Mendes SS, Martino MMF. Shift work: overall health state related to sleep in nursing workers. Rev Esc Enferm USP [Internet]. 2012 [cited 2013 Oct 11];46(6):1471-6. Available from: http://www.scielo.br/pdf/reeusp/v46n6/en_26.pdf

17. World Health Organization; American Cancer Society; International Union Against Cancer. Tobacco control country profiles. 2nd ed. Geneva; 2003.

18. World Health Organization; WHO Consultation on Obesity. Obesity: preventing and managing the global epidemic. Report of a WHO consultation. Geneva: WHO; 2000.

19. Figle NB, Pillon SC, Dunn J, Laranjeira R. The frequency of smoking and problem drinking among general hospital inpatients in Brazil: using the AUDIT and Fagerström Questionnaires. São Paulo Med J. 2000;118(5):139-43.

20. Barros AJD, Hirakata VN. Alternatives for logistic regression in cross-sectional studies: an empirical comparison of models that directly estimate the prevalence ratio. BMC Med Res Methodol [Internet]. 2003 [cited 2013 Oct 11];3:21. Available from: http://www.ncbi.nlm.nih.gov/pmc/articles/ PMC521200/
21. Mesquita G, Ferreira S, Rossini S, Soares EA, Reimão R. Efeitos do tabaco e o consumo de álcool sobre a qualidade do sono dos estudantes universitários. Neurobiologia. 2011; 74(1):19-27.

22. Vinson DC, Manning BK, Galliher JM, Dickinson LM, Pace WD, Turner BJ. Alcohol and sleep problems in primary care patients: a report from the AAFP National Research Network. Ann Fam Med. 2010;8(6):484-92.

23. Tomfohr L, Pung MA, Edwards KM, Dimsdale JE. Racial differences in sleep architecture: the role of ethnic discrimination. Biol Psychol. 2012; 89(1):34-8.

24. Mak KK, Ho SY, Thomas GN, Lo WS, Cheuk DKL, Lai YK, et al. Smoking and sleep disorders in Chinese adolescents. Sleep Med. 2010;11(3):268-73.

25. Yolton K, Xu Y, Khoury J, Succop P, Lanphear B, Beebe DW, et al. Associations between secondhand smoke exposure and sleep patterns in children. Pediatrics. 2010; 125(2):261-8.

26. Amorim AVC, Kikko EO, Abrantes MM, Andrade VLA. Álcool e alcoolismo: estudo de prevalência entre discentes do curso de Medicina da UNIFENAS em Belo Horizonte-Minas Gerais. Rev Med Min Gerais. 2008;18(1):16-23.

27. Myers MG, Doran NM, Edland SD, Schweizer CA, Wall TL. Cigarette smoking initiation during college predicts future alcohol involvement: a matched-samples study. J Stud Alcohol Drugs. 2013;74(6):909-16.

28. Maia APL, Sousa IC, Azevedo CVM. Effect of morning exercise in sunlight on the sleep-wake cycle in adolescents. Psychol Neurosci. 2011;4(3):323-31.

29. Perlow L. Sleeping with your smartphone: how to break the 24/7 habit and change the way you work. Boston: Harvard Business Press Books; 2012.

30. Li Q, Zheng T, Holford TR, Boyle P, Zhang Y, Dai M. Light at night and breast cancer risk: results from a population-based case-control study in Connecticut, USA. Cancer Causes Control. 2010;21(12):2281-5.

\section{Financial support:}

Conselho Nacional de Desenvolvimento Científico e Tecnológico (CNPq) by process n 474902/009-9. 